\title{
The Czech Nobility's Use of the Right of Patronage on Behalf of the Hussite Reform Movement
}

Throughout European history the aristocracy has been involved in reform movements which undermined either ecclesiastical or monarchical power structures. Thus the nobles of southern France in the twelfth century granted protection to the Cathars, and in fourteenth-century England lords and knights offered aid to the Lollards. The support of German princes and knights for Lutheranism is well known, as is the instrumental role played by the French aristocracy in initiating the constitutional reforms which gave birth to that nation's eighteenth-century revolution. The fifteenth-century Hussite reform movement in Bohemia similarly received aid from the noble class. Here, when the Hussites were under attack in 1417 from the authorities, especially the archbishop, sympathetic lords protected Hussite priests on their domains.

At the beginning of the fifteenth century three intellectual tendencies coalesced at the University of Prague, giving the Czech reform movement its basic character for the next fifteen to twenty years. The oldest was the religious pietism to which men like Matthew of Janov and Thomas of Stitný had given expression. In their quest for a renewed spiritual life they invited believers to participate personally and directly in religion, and called on the clergy to give up their lives of pleasure and wealth. At the same time there developed a Czech consciousness among the reformers as it became apparent that those interested in religious renewal were mostly Czech speaking, while their opponents, who held many of the coveted and important church and university offices, were foreigners. Lastly, it was at about this time that John Wyclif's program for church reform, under the aegis of the secular ruler, was introduced to Bohemia. The masters at the University of Prague adapted it to their situation, hoping first for the king's aid, but when this proved futile they courted the nobility. Because powerful and wealthy prelates sought to put an end to their freedom to agitate for reform, the reformers needed authoritative and official help. Led by John Hus, the university masters adopted Wyclif's ideology, through which, with the help of legitimate secular authorities, they sought to bring an orderly change in the religious life of the land.

From 1402 to 1408 the reformers worked in cooperation with Archbishop

The author wishes to thank the Canada Council, and the Canadian people, for the financial support provided for research for this article. 
Zbynèk, a member of the baronial Hazmburk family, whose brother-in-law was Hus's patron at Bethlehem Chapel. However, under pressure from the canons of Saint Vitus Cathedral in Prague castle and from the reformers' enemies at the university, the archbishop and the Wyclifites in 1408 parted ways, charging each other with holding unorthodox views. ${ }^{1}$ Until 1412 the reformers received legitimacy from King Wenceslas, who, because of his own struggles with the German princes, needed the cooperation of the university. The king, however, broke with the Hussites when they opposed the sale of indulgences. This money was intended for the 1411 crusade of Pope John XXIII against Gregory XII, but the king also hoped to gain financially. ${ }^{2}$

Having lost the support of both the ecclesiastical hierarchy and the king, the reformers turned to the nobility. In the 1390s the nobles, through armed leagues, had forced the king to give them control of the government of the land. ${ }^{3}$ As a result, their support of the reformers had the potential of giving them legitimacy. Their opportunity came in September 1412, when pressure on the reformers was intensified by a papal interdict, stopping all religious services, proclaimed over Prague because Hus had refused to answer a citation in Rome. Several nobles protected Hus in their castles from 1412 to 1414. But their attempt to use the governmental institutions, such as the Diet or the land court, to settle the quarrel between the reformers and the local church at home was unsuccessful, because they were unable to convince the majority of nobles. Their failure to induce the land government to act on behalf of the movement meant that the only concrete aid Hussite nobles could offer the reformers was access to the parishes and church offices to which they owned patronage.

When it proved impossible to resolve the religious discord at home, Hus, as a last resort, in the fall of 1414, went to Constance to lay his case before the gathering council of church fathers. The Council of Constance responded by burning Hus as a heretic on July 6,1415 , and by condemning the beliefs espoused by his followers, including the taking of wine as part of communion (utraquism). Through letters to Emperor Sigismund, the convoker of the Council and heir apparent to the Bohemian crown, the Hussite nobles tried unsuccessfully to intervene on Hus's behalf. Their last letter of

1. See Václav Novotný, M. Jan Hus, život a učeni, 2 vols. (Prague, 1919-21), 1:14250; V. V. Tomek, Dějepis města Prahy, 12 vols. in 11 (Prague, 1855-1901), 3:447-49. Jan Sedlák, M. Jan Hus (Prague, 1915), pp. 103-7, stressed the cooperation between Hus and the archbishop in the early years.

2. F. M. Bartoš, Cechy v době Husově (Prague, 1947), pp. 291-314 and 352-53. Cf. Howard Kaminsky, A History of the Hussite Revolution (Berkeley and Los Angeles, 1967), pp. 66-67, 80.

3. I use the term "land" as defined by Otto Brunner, Land und Herrschaft, 6th ed. (Darmstadt, 1970), pp. 181-94. That is, it refers to an association of lords (Grundherren) who owned land and formed a political structure called a land community (Landesgemeinde) having a uniform law and custom defined by the land court. 
September 2,1415, to the Council, from which were suspended the seals of some 320 Bohemian and 130 Moravian noblemen, rebuked the church fathers for their unchristian behavior in burning Hus, and was the most dramatic and widespread display of noble support for the movement. ${ }^{4}$

Among the Hussites were some of the most powerful barons in the land, including Čeněk of Vartemberk, who as chief burgrave in some ways was equal in authority to the king. On the whole, however, the Hussites represented only about 20 percent of the nobility. The thirty-three barons made up a little over 22 percent of the 145 persons of baronial status living in Bohemia from 1415 to 1434 . The 287 Hussite members of the gentry represented 240 families, that is, 17 percent of the 1433 gentry families living at the beginning of the fifteenth century. ${ }^{5}$ In terms of owning church patronage, Hussite nobles were somewhat poorer than their Catholic peers. The Hussite gentry owned not quite 6 percent of the 731 parishes to which the gentry as a class owned patronage, that is, more than 10 percentage points below what they would have held if they had owned patronage according to their number. Among the barons the discrepancy was smaller; Hussite barons owned 20 percent of the 478 parishes held by the upper nobility as a class. Militarily the Hussites were also outnumbered, since Hussite barons owned ninety castles compared to the two hundred in Catholic hands. ${ }^{6}$

The protest letter was part of a larger program of action undertaken by the nobility in its role as the protector of the Hussite reform movement. On September 6 the Hussite barons formed a league which, in addition to arranging for its letter to be sent to Constance, provided guidelines for joint action in order to protect the Hussite religion. As captains it named three leading barons, Ceněk of Vartemberk and Boček of Poděbrady from Bohemia, and Lacek of Kravaře from Moravia, under whose direction the rest were to act. The most significant feature was the promise of mutual aid according to which as patrons they were to protect their priests against any and all ecclesiastical citations and excommunications. ${ }^{7}$ With this the nobles reasserted

4. The letters were collected by Václav Novotný, Hus v Kostnici a česká šlechta (Prague, 1915).

5. In counting the gentry families I used the material collected by August Sedláček, Hrady, zámky a torze království českého, 15 vols. (Prague, 1880-1927; 2nd ed., 1931-36), Usually I counted one family per fortress or estate unless Sedláček specifically stated that several owned it. The question is made complex by the fact that we find several persons named after a given fortress at about the same time, but we do not know whether they were of one family. The baronial families were compiled partly by František Kavka, "Strana Zikmundová v husitské revoluci" (dissertation at Charles University, Prague, 1947). The remainder are found in Novotny's Kostnici, p. 45.

6. On patronage ownership see my dissertation, "Noble Patronage and Politics in the Hussite Revolution" (University of Washington, Seattle, 1973), chap. 5. See also my forthcoming article in Archive for Reformation History, to be published in 1975. For the number of castles see Kavka, "Strana," pp. 17-18.

7. See Kaminsky, $H H R$, pp. $144-45$, for a translation of a substantial part of the 
their rights of patronage, using them on behalf of the new religious movement.

The right of the patron to present a priest to a parish went back to the time when the demesne lord, having built a church on his land, as its owner placed one of his men in it as the priest. The principle of lay ownership of parishes, where the lay lord controlled the economic base of the parish, came under attack by the popes in the twelfth century. Thereafter, according to canonical principles, a parish was to have an independent source of income in the form of an endowment from the landowner, and the investiture of the priest into office was to be reserved to the bishop. The right of the patron was restricted to presenting or proposing a priest to the episcopal office for confirmation. But it was not until the fourteenth century that these prescriptions were enforced in Bohemia. Two men from the baronial ranks, John of Dražice, bishop of Prague from 1301 to 1343, and Ernest of Pardubice, archbishop from 1344 to 1364 , succeeded in establishing to a large degree at least the letter of church law over the relation between patron and priest. By the end of the fourteenth century over 90 percent of the patrons in the Prague diocese submitted their priests to the archbishop's office for approval. ${ }^{8}$ The September 6, 1415, pact of the Hussite nobles was in a sense a declaration that they were prepared to return to the conditions of the pre-fourteenthcentury period. If the church did not grant freedom to Hussite priests, the patrons were going to protect their priests and install them in office even without episcopal confirmation.

There are several reports from the period after Hus's death referring to violence done to Catholic priests by the nobility. For example, in a letter of March 27, 1416, the Council of Constance, writing to the Catholic nobility in Bohemia, complained, "Priests, both regular and secular, are being despoiled, driven away from their benefices, injured, killed, and horribly treated, against the liberty of the Church." Similarly two chronicles of the period refer to difficulties suffered by the Catholic clergy at the hands of the nobles. The Hussite chronicler, Laurence of Březová, wrote: "After the death of John Hus the perverse clergy . . . were by just judgment of God afflicted every day, by having their property taken away by laymen, by being ejected from their places and offices. ..."10 The writer of the chronicle of the University of Prague made a similar point.

pact, and František Palacký, ed., Documenta Mag. Joannis Hus (Prague, 1869), pp. 59093, for the original text.

8. See H. E. Feine, Kirchliche Rechtsgeschichte, 2 vols. (Weimar, 1955), 1:234 and passim; H. F. Schmid, "Die rechtlichen Grundlagen der Pfarrorganisation auf westslavischem Boden," Zeitschrift der Savigny-Stiftung für Rechtsgeschichte, 15 (1926): 154; Rostislav Nový, "K sociálnímu postavení farského kléru v Cechách v době předhusitské," Sbornik historicky, 9 (1962): 164-65. See also the dissertation cited above in note 6.

9. Palacký, Documenta, p. 618; Kaminsky, HHR, p. 155.

10. Jaroslav Goll, ed., Fontes rerum Bohemicarum, 7 vols. (Prague, 1873-1932), 
These reports have led major historians of the period such as František Palacký, F. M. Bartoš, and Howard Kaminsky to the conclusion that shortly after its formation the Hussite league went on the offensive against the ecclesiastical hierarchy. ${ }^{11}$ No doubt such reports reflect, at least partly, events in Bohemia in that they deal with activities by which Hussite priests gained offices at the expense of Catholics. The archbishop's enforcement of the interdict in the fall of 1415 , when all Romanist clergy ceased performing worship services only to be replaced by eager Hussites, probably contributed to such a state of affairs.

It was not, however, the Hussite league which was to blame for this, and reports to that effect cannot be taken at face value. In the first place, the writers of the Council's letter in March 1416 were far from the scene, and they might easily have exaggerated the significance of reports of the formation of noble leagues and of violence coming from Bohemia. Perhaps they confused the turnover of November 1415 with the stated intention of the Hussite league to defend its clergy. Similarly, Laurence of Březová, who wrote in the 1420 s, was imprecise, not saying when and by whose hand God punished his enemies. If he had in mind the Hussite nobility, he must have been referring to their actions in 1417 and after. Lastly, the writer of the university chronicle referred only to the city of Prague, claiming that Catholics were expelled from office sometime between 1415 and 1419. The Hussite nobles were not responsible for events in Prague, a royal city, where they themselves owned no patronage. ${ }^{12}$

There is a more reliable source for a study of the nobility's action on behalf of their priests than letters and chronicles. That is the episcopal records of confirmations to church offices, the Libri Confirmationum, published in the nineteenth century but never thoroughly analyzed. ${ }^{13}$ These records throw a great deal of light on the relationship between the nobility and the reformers. They show, first, that already before 1417 a small group of nobles had begun to use their rights of patronage on behalf of Hussites and, second, that the campaign begun in January 1417 to turn Romanist priests out

5:338; cf. Kaminsky, $H H R$, p. 155. For the university chronicler's reference see František Palacký, Dëjiny národu éeského, 5 vols. (Prague, 1939, reprint of the 1871 edition; first publ. 1848-67), 3: 184.

11. Palacký, Dëjiny, 3:184; F. M. Bartoš, Husitská revoluce, 2 vols. (Prague, 196567), 1:20-21; and Kaminsky, $H H R$, pp. 146-48.

12. The attack on the monastery in Opatovice at the beginning of November 1415 may have appeared to the Council as an act of the Hussite nobility. But this event was unrelated to Hussite politics, since both Hussites and Catholics participated in it. See Josef Kalousek, "Záští ve východních Cechách," Casopis Musea královstvi českého, 77 (1903) : 275-79. For patronage ownership in Prague see Tomek, Dějepis, 3:144.

13. Josef Emler and František Tingl, eds., Libri Confirmationum ad beneficia ecclesiastica Pragensem per archidioecesim (1354-1436), 10 vols. in 8 (Prague, 1865-89) (hereafter cited as $L C$ ). 
of office in favor of Hussites was a defensive reaction. The nobles did not initiate the attack but responded to the archbishop's offensive against their clergy, which had begun in January. In doing so, the Hussite nobles provided the reformers with authoritative support and a degree of legitimacy during a period of crisis for the movement: from 1417 to the outbreak of the revolution in late 1419.

As sympathy for the Hussites grew among the nobility in the years before Hus's death, one might expect that nobles would have used their rights of patronage to fill their churches with Hussites. The available evidence shows this to be only partly true. A study of this problem is made difficult by the fact that only a small number of confirmed priests can be identified according to their stance on the religious questions of their day. However, since the home of the reform movement was the University of Prague, we can get some idea of how extensively the nobility had offered its patronage to the reformers by examining the frequency with which members of the university population appeared in the confirmation records.

Between 1400 and 1415 the noble estate did not make use of its patronage on behalf of university students any more than other classes did; in fact, since it owned two-thirds of the patronage, proportionately less. The table opposite shows the number of times the right of patronage was exercised on behalf of university students by the various classes. Some students, mostly masters, appeared in the confirmation records more than once and had more than one patron, because they held several offices either simultaneously or consecutively. Only a few of these, however, were Hussites.

A comparison of the names of the masters present at the 1411 Quodlibet, a disputation held on the university's anniversary, with those masters appearing in the archbishop's confirmation records shows to what extent those associated with Hus had found patrons. The 1411 Quodlibet was basically a Hussite affair. Sixty-one of the sixty-six masters present were native Bohemians, the group in which the Hussites found most of their support. Hus, the major speaker, was under papal anathema and had been cited to Rome to answer charges of heresy. Under these circumstances, except for perhaps a few observers from the Catholic party, most of those attending were undoubtedly friendly to his cause. ${ }^{14}$ By 1415 , two-thirds of the sixty-six masters had not been confirmed to any church office. The developing alliance between nobility and Hussite university students had begun to result in church offices

14. Bohumil Ryba, ed., Magistri Iohannis Hus. Quodlibet (Prague, 1948), pp. 21920. See Sedlák, M. Jan Hus, pp. 193-94. Of those present, four were known enemies of the reformers: Nicholas Cacabus, Gregory of Prague, Procop of Kladruby, and John of Beroun. Twenty-six were known Hussites. The stance of the rest is unknown. See also F. M. Bartoš, "Musejní sborník s Husovým kvodlibetem," Casopis Národního milsea, 112 (1938) : 188-97. 
Patronage on Behalf of University of Prague Students, 1400-1415

\begin{tabular}{lcccccr}
\hline & \multicolumn{6}{c}{ Patrons } \\
\cline { 2 - 7 } Period & Royal & Noble & $\begin{array}{c}\text { Towns- } \\
\text { people }\end{array}$ & $\begin{array}{l}\text { Secular } \\
\text { clergy }\end{array}$ & $\begin{array}{c}\text { Religious } \\
\text { orders }\end{array}$ & Total \\
\hline 1400-1405 & & 2 & 0 & 0 & 0 & 2 \\
$\begin{array}{l}\text { Nonmatriculated } \\
\text { Bachelor of arts }\end{array}$ & 0 & 2 & 0 & 0 & 0 & 2 \\
Master of arts & 3 & 5 & 5 & $61 / 2$ & $31 / 2$ & 23 \\
1405-1410 & & & & & & \\
Nonmatriculated & 0 & $31 / 2$ & 0 & $11 / 2$ & 1 & 6 \\
Bachelor of arts & 0 & 5 & 1 & 0 & 0 & 6 \\
Master of arts & 2 & 12 & 10 & $31 / 2$ & $71 / 2$ & 35 \\
1410-1415 & & & & & & \\
Nonmatriculated & 0 & 0 & 1 & 0 & 1 & 2 \\
Bachelor of arts & 0 & 1 & 0 & 1 & 1 & 3 \\
Master of arts & 5 & 7 & 3 & 7 & 3 & 25 \\
$\quad$ TotaL & 10 & $371 / 2$ & 20 & $191 / 2$ & 17 & 104 \\
\hline
\end{tabular}

Notes: The designation of one-half person indicates that patronage was shared between members of different classes. The number of masters is approximate, since it includes two persons designated M. Peter, two designated M. Stibor, and one M. Stephen (along with three other Stephens identified by place of origin), who were not well enough identified to tell if the name represented one or more persons. Two priests confirmed were identified as students without degrees. The remaining nonmatriculated students who were also priests were found in the register of the law faculty, which also gave the name of their church office. See Monnmenta historica universitatis Carolo-Ferdinandeae Pragensis, 2, no. 1 (1834). Their patrons were then identified from the $L C$. Mostly these were not presented to office as students but became students after confirmation as priests. The term "student" here refers to all categories, including postgraduate.

for some of the latter. There was, however, no general effort on the part of those nobles who later appeared in the Hussite camp to act as patrons on behalf of Hussites.

The tenuous relationship between university students and Hussite nobles is reflected in the fact that of the forty noble patrons of students, only five protested Hus's condemnation and death to the Council of Constance in 1415..$^{15}$ Three of the five priests were known Wyclifites: Master John Kardinál, Jacob of Soběslav, ${ }^{\mathbf{1 6}}$ and Nicholas of Pelhřmov. Two other students received offices through the patronage of persons associated with Hussitism. In 1407 the squire Mikeš of Ulibice, who eventually fought alongside Cenĕk of Vartemberk in the Hussite Wars, presented a university student to the parish in Nemojčeves, ${ }^{17}$ and Margaret of Peruce, a noblewoman living in the com-

15. Boček of Poděbrady in Jeseník, $L C, 6: 207$; Peter Janovice of Chlumec in Janovice, $L C, 7: 100$; John of Vlaším in Kondratice, 7:131; and two squires, Leonard of Luky and Peter Malovec of Pacov, 6:215 and 7:12.

16. Peter Malovec presented M. Jacob, whom I take to be M. Jacob of Soběslav, a friend of Hus's. See Novotný, M. Jan Hus, 1:453.

17. LC, 6:226; cf. Sedláček, Hrady, 5:207. 
munity of pious women near the reformers' Bethlehem Chapel, was one of the patrons who presented Egidius, Bachelor of Arts, to the parish in Chlumčany in $1400 .{ }^{18}$ Lord Henry of Rožmberk's patronage of university students suggests that he also favored them. He supplied offices to seven members of the university community, one of whom, Thomas of Lysá, was a leading Wyclifite and friend of Hus's. ${ }^{19}$ We know that Henry's wife sympathized with the reformers, and possibly the Rožmberks brought their young friend, Ceněk of Vartemberk, later one of the most powerful Hussites, into contact with the university masters.

We have not exhausted all the possible patronage bestowed by the nobility on either Hussites or university students. Only those who can be identified either as student or Hussite have been included. The question of how many priests, of whom we know only their names and sometimes place of origin and who had perhaps attended the university for a year, adopted Wyclifite ideas, dropped out, and then were confirmed to a parish cannot therefore be answered conclusively. Only if a priest later became notorious, such as Peter Hromádka, is it possible to identify him. ${ }^{20}$ Nevertheless, it is evident that although until 1415 the nobility, including the Hussites, had not extensively put their patronage at the disposal of the university students, there existed a select group of eight nobles who had early recognized the possibilities inherent in their positions for assisting them to find jobs and spread their ideas.

The Hussite league of September 6, 1415, had taken pains to show that they considered their action lawful and that their members were prepared to maintain a legitimate relationship with the ecclesiastical structure. In their pact the nobles had specified that their priests were subordinate to the Romanist bishops and would answer to them if charged with any error. They added that they would accept a decision on a priest's guilt or innocence only if it were based on the Word of God. ${ }^{21}$ Presumably they intended to recognize the patronage rights of ecclesiastical institutions on their estates and to follow the established procedures of presenting priests for confirmation to the archbishop's office. In the year immediately following the formation of the league,

18. $L C, 6: 26$.

19. Four of these were masters: 1402 (Sedlčany), 1407 (Mlazov), 1407 (Nezvěstice), and 1408 (Sviny). See $L C, 6: 75,225$ (cf. p. 160), 220, and 247. The seventh, Andrew, the priest in Chotovice, was in the law faculty. See Monumenta historica universitatis Carolo-Ferdinandeae Pragensis, 2, no. 1 (1834): 41.

20. Peter's patron in 1413 was a squire John of Strrimelice, $L C, 7: 100$. Cf. Kaminsky, $H H R$, p. 281 , n. 60 . In addition there were other forms of patronage, as when John of Jesenice in 1409 got the right to collect an annual revenue on one of Lord John of Chlum's estates. See Jiří Kejř, Husitský právník M. Jan z Jesenice (Prague, 1965), pp. 94-95.

21. See above, note 7. 
the Hussite nobility did not find it necessary to oppose the episcopal office, and each continued to recognize the other's jurisdiction.

Until 1417 the archbishop took no action against Hussite patrons and continued to confirm their priests. On December 28, 1416, a priest proposed by Lord Cenèk was confirmed by the archbishop's office. This was the noble's last presentation of a new priest, although he consented to three exchanges involving his priests in 1417 and one in 1418, all of whom were canonically confirmed. ${ }^{22}$ The churches in question were in the northeast, where the archbishop's investigative machinery had not yet reached. Boček of Poděbrady, along with Ceněk, a captain of the league, presented a priest to the episcopal office for the last time on April 28, 1417. His candidate did not have to take the oath against utraquism and Wyclifism, although eight days earlier the archbishop had begun to administer it. ${ }^{23}$ The priests of other Hussite barons were also confirmed by the archbishop throughout 1416 . The last man to be presented by Hynek Krušina of Lichtenburk was confirmed on August 7, that of Mikeš of Žampach on September 22, and that of John Sádlo of Kostelec on April 11.24

In a year like 1416, in which the archbishop and the king pursued a weak and temporizing policy with respect to prosecuting the Hussites, there were accepted ways in which a patron could rid himself of an unwanted priest without violating normal procedures. For one thing it was permitted for priests to exchange offices, but even this device was not made use of by Hussites to any great extent. From September 2, 1415, until the end of 1416, two such exchanges involving Hussite patrons are recorded in the episcopal records. ${ }^{25}$ We cannot say whether or not Hussite politics lay behind these exchanges, because the religious views of the patrons of the other two churches affected are not known.

A related case involved a parish belonging to Albert of Tèchobuze, a burgrave of the Rožmberk castle, Přibenice, hence in Cenĕk's service, since he was the Rožmberk guardian. Albert had attached his seal to the September 2

22. $L C, 7: 214$. The three exchanges, confirmed after March 2, 1417, when the baron and the archbishop parted ways, occurred in northeastern Bohemia, on Ceněk's own domains. This may account for the fact that these confirmations appear in the episcopal records even though Ceněk's placements in the Rožmberk churches do not. It was in the south that Ceněk followed an active policy on behalf of the Hussites. For the exchanges see $L C, 7: 232,227,255-$ Vapno, Skalice, and Koleš.

23. Ibid., p. 225.

24. Ibid., pp. 207, 209, 199.

25. On July 6, 1416, John of Hrádek's priest exchanged with the one in Smečno (ibid., p. 205). On January 7, 1416, the priest of Diviš and Zaviš of Pertoltice exchanged with the one in Bykañ (p. 186). Perhaps Kozmice was a similar case. On August 7 the priest of Wenceslas of Kozmice exchanged with the one in Rataje (p. 207). For the squire of Kozmice see August Sedláček, "Úvahy o osobách v stižných listech 1. 1415 psaných," Ceský časopis historický, 23 (1917) : 315. 
protest letter, and on May 18, 1416, his priest in Zahor was confirmed in Borovnice, vacant by the death of the last rector, whose patrons were the archbishop and a local squire. The priest whom Albert presented to Zahor also received episcopal confirmation. ${ }^{26}$ This may have been a normal move of priests to parishes more to their liking. On the other hand, Albert may have wanted to get rid of his priest for doctrinal reasons and the archbishop conveniently found a vacant parish for him.

There was one case in 1416 in which a Hussite patron may have expelled a priest without bothering to present his replacement to the archbishop's office; or if he did, he did not receive confirmation. On November 12, John, the former priest in Hroby, went to the church of Saint Adalbert in Prague under the patronage of the Catholic baron, Peter of Šternberk, in what was called an exchange. The patron in Hroby in 1415 had been Hrdibor of Stipoklasy. The estate of that name belonged to the Zbraslavice domain, whose owner, John Podolec, affixed his seal to the letter of September $2 .{ }^{27}$ It may be that Podolec, as a Hussite enforcing his religious principles, was behind the decision to get rid of the priest in Hroby.

Another way in which a patron could get rid of a priest without violating episcopal procedure was simply to have the office declared vacant by resignation and appoint another priest. Usually a confirmation entry in the records included the reason for the departure of the last rector-namely, death or resignation for a variety of reasons. A significant number of entries gave no reason for the resignation, probably because it was forced from the incumbent by the patron. In 1416 no reason was given for 21 percent of the vacancies, a rise of seven points from the previous year. ${ }^{28}$ Unexplained resignations were not, however, the work of Hussites. On the contrary, it was Romanist patrons who were declaring offices vacant with no explanation and presenting other priests. Thus, known enemies of the Hussite movement, such as Lords Otto of Bergov and Hynek Berka of Lipá, ${ }^{29}$ as well as ecclesiastics such as the abbots of various monasteries, ${ }^{30}$ Albik, the provost of the Vyšehrad Cathedral, ${ }^{31}$ and the archbishop, ${ }^{32}$ appointed priests after they had had the episcopal vicar-general declare the offices vacant.

Only one such case involved a patron associated with the Hussite cause. This was in Skryje, where the priest resigned on October 11, 1415, without

26. $L C, 7: 202-3$.

27. Ibid., p. 211; cf. Sedláček, Hrady, 7:177.

28. The highest percentage was in 1407 , when it reached 25 percent. See Klassen, "Noble Patronage and Politics," p. 69.

29. $L C, 7: 205,201-2$.

30. Ibid., pp. 186, 191, 192, 196, 202, 203, 204.

31. Ibid., p. 206.

32. Ibid., p. 209, two times. 
an explanation. ${ }^{33}$ The patrons here were Nicholas of Husinec (well known for his Hussite sympathies), his step sons, and another local squire. The conclusion that Nicholas presented a Hussite after he had compelled the last one to resign seems inescapable. Why then did the archbishop's vicar-general, who was responsible for confirmations and who pursued a committed course in opposition to the Hussite movement, confirm Nicholas's priest? The reason is that throughout the years the episcopal office and lay patrons had worked out a modus vivendi; the noble patron recognized the archbishop's right to confirm and install his priest, and in return the archbishop honored the noble's choice for priest. This relationship continued until 1417, and except for the two cases in which Hussite patrons may have been active, there is no evidence of a general changeover of priests caused by the Hussite noble league in 1416. If the Hussite nobility had already begun a wholesale replacement of Catholic priests with Hussites, including churches over which they did not own the patronage, the episcopal office would have objected, as it did in 1417 when a Catholic noble took over a monastery's right.

The year 1417, on the other hand, was crucial for the Hussite movement. Early in the year both king and archbishop embarked on a vigorous policy aimed at suppressing Hussitism. At the same time radical tendencies within the movement, seeking more far-reaching changes in ecclesiastical life, had become more noticeable, alienating some nobles and jeopardizing the much-needed support which the university leadership had carefully fostered among the nobility. In this situation - their movement under attack from the outside and undermined from the inside-the noble friends of Wyclifism and utraquism responded by using their authority as patrons. Fulfilling the terms of their September 6, 1415, pact, they defended their priests from ecclesiastical citations and then, in order to bring the radicals into the moderate mainstream of the movement, they provided them with parishes.

Already in December 1416, King Wenceslas, under pressure from the Council of Constance and his brother Sigismund, had forced the university to conform to his policy of a Catholic restoration. Royal decrees of December 2 expressed a settlement between the university and the archbishop, according to which all property that had been seized was to be restored, expelled Catholic priests were to be reinstated, and the reformer lawyer, John of Jesenice, the cause of the interdict, was to leave Prague. As a concession to the Hussites, utraquism was permitted in certain churches. ${ }^{34}$ But the hoped for peace was not to be. Mast of the Hussites, led by Jakoubek of Stribro, declined to comply with the king's orders. The Catholic clergy of Saint Vitus Cathedral

33. Ibid., p. 177; Martin of Lipnice, a town belonging to Cenèk, was presented.

34. For Jesenice see Kejř, Husitský právnik; for the settlement see Kaminsky, HHR, pp. 224-25. 
refused to return to their offices and resume services, saying that neither churches nor property had been returned to their former owners.

More important for the Hussites was the archbishop's action at the beginning of 1417 which in effect made it necessary for the nobles to defend their clergy. After this they found themselves forced to act in defiance of the archbishop's office if they wanted to sustain their religion. On January 10 the archbishop published the Council's decree condemning utraquism and declared that henceforth he would neither ordain nor confirm into office any utraquist priest. Next, in order to remove those Hussites already in possession of church offices, he ordered his rural deans to convoke the parish priests for the purpose of ferreting out violators of the Council's instructions. ${ }^{35}$ Furthermore, to keep any new Hussite priests from taking office, the archbishop instituted a special oath whereby priests being confirmed swore that they would not administer wine as part of communion nor would they hold the forty-five condemned Wyclifite articles. On March 3, 1417, the first Hussite priests were deprived of office for reasons of faith, and on April 8 the oath abjuring Hussitism appeared for the first time. ${ }^{36}$

At the same time that the archbishop adopted his aggressive policy toward the Hussites, various trends developing within the Hussite movement began to threaten its unity. Some of the more radical tendencies with their far-reaching plans for reform had become a concern to the moderate leaders of the university-nobility coalition. The radicals wanted to reduce religious life to its most simple form. They denied the existence of purgatory and the usefulness of giving alms for the dead, and questioned the value of venerating the images of Christ and the saints, as well as a whole series of ceremonial and thaumaturgic rituals connected with the church's worship. Lastly, in keeping with the central position which the ceremony of the eucharist had assumed in the movement, they insisted that infants also partake in communion. ${ }^{37}$ The moderates feared that the radicals, with their espousal of these Waldensian tenets, not only obstructed any efforts to get European acceptance for their reforms but also placed their whole cause in jeopardy at home in that they induced some nobles to defect to the opposition.

35. Kaminsky, $H H R$, p. 227, esp. n. 21.

36. $L C, 7: 220,224$; cf. Kaminsky, $H H R$, pp. $240-41$, notes 53 and 54 . For a full wording of the oath see $L C, 7: 232$ : "Juravitque ibidem articulos Wicleff et non communicare sub utraque specie." A study of the oath and to whose priests it was administered is singularly uninformative. Neither the identity of the patrons whose priests took the oath nor their geographical location suggests a pattern. The priests of abbots and other Catholic patrons took it, as did those whose patrons were Hussites. On the other hand priests of some Hussites, such as Boček of Poděbrady, did not take it. Some priests from all over the diocese took it; from the southeast, the home of Hussite nobles, as well as those from Catholic areas near Plzen in the west. It seems the archbishop administered it to a random sampling of priests.

37. Kaminsky, $H H R$, pp. $230-34$. 
Lord Cenèk of Vartemberk, at the end of 1416 and the beginning of 1417 , took several steps aimed at reconciling the Hussite movement with the church. In a gesture which was also intended to repair his relations with the future king, King Sigismund of Hungary, Cenèk accepted his offer, made in March 1416, to mediate the dispute between the Hussite barons and the Council. ${ }^{38}$ In response to his prodding, the university on January 25 and February 7, 1417, issued public statements exhorting all to believe in purgatory, to continue to offer prayers, alms, and other suffrages for the dead, and to venerate the images of Jesus and the saints during worship, as well as observe various ceremonies such as bell-ringing and blessing of grains, cheeses, and eggs. ${ }^{39}$

The archbishop's campaign of suppression, launched at this same time, however, wrecked the hopes for a reconciliation between Hussites and Catholics and compelled Lord Ceněk to take steps to consolidate the Hussite church by regulating the status of the Hussite clergy, while at the same time bringing the more radical priests into an established Hussitism. There was no dearth of volunteers willing to take to the pulpits in the name of the chalice and the freedom to preach the Word of God. The problem was that in addition to spreading acceptable Hussite ideas these men were also preaching tenets condemned by the university and sometimes indulging in behavior deemed scandalous by the moderate Hussites. The problem was to regulate their own clergy so that in case of scandal there would not be a bad reflection on the Hussite movement. To meet this need for qualified priests, Čeněk on March 6 abducted Herman, the titular bishop of Nicopolis and suffragan bishop of Prague, to his castle Lipnice, where his father-in-law had endowed a collegiate church. Here Herman ordained priests for the Hussite church, including some of the younger men whom Ceněk hoped to draw from their radicalism into a more moderate stance by giving them a regular place and living. ${ }^{40}$

Later, on June 17, in an effort to strengthen the Hussite position on the extensive Rožmberk domains, where his guardianship ran out when young Ulrich came of age in January 1418, Ceněk announced that henceforth communion was to be administered in both kinds, bread and wine, and that any cleric not willing to accept this would be replaced by one who was. As part of this action, as Kaminsky has shown, Cenĕk placed some fifteen priests into vacated Rožmberk parishes, most of whom had been ordained at Lipnice. ${ }^{41}$

After the onset of the archbishop's attack, Hussite priests were no longer confirmed to their parishes, either because their patrons did not present them

38. Bartoš, Husitská revoluce, 1:35-36.

39. Kaminsky, $H H R$, pp. 230-40. Cf. Palacký, Documenta, pp. 633, 654-56.

40. Kaminsky, $H H R$, pp. 242-44, and Sedláček, Hrady, 12:70-71.

41. Kaminsky, $H H R$, pp. 244-46. 
to the episcopal office or because the officials refused them. Evidence of Hussite patronage can nevertheless be found in the Libri Confirmationum. For example, frequently the confirmation statement of an orthodox priest identified him well enough so that he can be traced to his last office. When the office from which he came had no corresponding confirmation and the patron of that benefice was a Hussite, we can be sure that he or she had removed a Catholic priest in favor of a Hussite.

The relatively high number of priests confirmed in 1417 who had left offices where Hussites were patrons supports the claim that 1417 was a decisive year for the Hussite nobility. In that year they expelled those of their priests who had cooperated with the archbishop's officials and their attempts to locate Hussite priests for disciplinary action. In addition, on March 10, 1417, the University of Prague officially declared itself in favor of utraquistic communion. Any priest who could not accept this practice, because of loyalty to the Roman faith and rite, was evidently dismissed if his patron was an utraquist. Thus a group of Hussite nobles were committed to the reform movement even though it meant open disobedience to the established church and medieval religious order. These nobles played an important role in helping the Hussite movement in a critical period by giving its priests parishes and security to conduct their ministry. From 1417 to late 1419 their domains were the only lands where Hussites enjoyed a legal status, while the rest of the realm drifted toward reaction.

Two of the priests whom Cenèk expelled are identifiable in the episcopal records. On April 26, 1417, the former priest in Sedlcany was confirmed in Kovařov with the consent of the patrons, the abbot of the monastery in Milevsko and the local squires. Sedlčany was a Rožmberk church where Lord Henry had presented Vlaštek in $1407 .{ }^{42}$ Similarly we know that Ceněk expelled the chaplain from Velešín, a Rožmberk office, sometime before July 20 , 1417 , because on that day John, the former chaplain there, went to Drahov under the patronage of William of Usti. As is to be expected, neither of the priests entering the two vacant Rožmberk churches received episcopal confirmation. ${ }^{43}$ In addition, Ceněk most likely used the legitimate device of the exchange to replace unwanted clerics. To this end he cooperated with Catholic patrons who found themselves with undesirable Hussite priests. Ceněk consented to exchanges involving three of his own churches in northeastern Bohemia. One of the exchanges affected a parish owned by Lord John of Michalovice, who in 1410 had supported the Wyclifites and had in that period

42. $L C, 6: 198,7: 230$. The confirmation states that Vlaštek came to Kovařov as a result of an exchange and that the priest there, Peter, had resigned. Whether Peter as a Hussite had previously left his parish and then found a patron in Ceněk is not known.

43. $L C, 7: 235$. 
placed one of them in that office. After returning to the Catholic fold in 1414 or 1415 he found the presence of a Hussite priest intolerable. ${ }^{44}$

Čenèk was not the only patron active on behalf of Hussites. The episcopal records show that at least ten other Hussite nobles, five of whom had signed the September 2 protest letter, expelled priests for religious reasons and replaced them with Hussites. Sometime before March 22 a Hussite, Albert of Těchobuze, and his copatrons expelled the priest John from his parish in Hodètice, where Albert, his brothers, and some other local squires had presented him in February 1415. John found another church under the patronage of the Catholic noble, Aleš Škopek of Dubá. Těchobuze had affixed his seal to the protest letter, as had Bušek and Pribek of Jedlany, who shared the patronage there in $1413 .^{45}$ Similarly, sometime before April 22, Boček of Poděbrady released Peter, his chaplain of the Náchod castle. Peter found a patron in the Catholic lord, Ulrich of Cerncice, whose rector in Dobenin resigned without explanation, perhaps to make room for Peter. ${ }^{46}$ By July 21 Ulrich Vavák of Hradec had expelled his priest, Peter, from the church in Straž, where he had presented him in March 1415. Peter was confirmed to an altar in Budèjovice on July 21, his patron being the local parish priest and a lady Johanka. ${ }^{47}$ The priest whom Nicholas of Dètenice expelled from Železný Brod (Brodec) did not find a patron until May 19, 1418, when a Catholic nobleman, Hrzek of Lypno, and a brother John of the monastery in Postoloprty presented him to a parish in Dobričany. Lord Nicholas had been his patron in 1414 when he came to Železný Brod. ${ }^{48}$ Lastly, from the ranks of the signers of the protest letter, John Medenec of Ratibor expelled the priest, John of Usti on the Lužnice, whom he had presented to the church in Smilovy Hory (Buchberg) in October 1415. In October 1418 the priest, John, found another church under the patronage of Charles and Bušek of Ričany. This family had been friendly to John Hus, but had evidently remained loyal to the Catholic Church once the reform movement had been

44. See above, note 22 .

45. In 1413 the patrons were the brothers Bohuslav, Bušek, and Olbram of Suchdol, John of Tremeč, Přibek of Jedlany, Bušek of Jedlany, Albert, Přibik, John, and Bossti of Stojice. See $L C, 7: 77$. In 1415 they were "Bohuslav Břekovec with his brothers and Albert of Stojice and of Těchobuze with his brothers" (ibid., p. 146). According to Václav Schulz's index in $L C, 7: 307$, based on František Palacký's Popis královstuŕ českého (Prague, 1948), the Hrádek (Hrdek) is Cervený Hrádek, that is, the estate of Herman, a member of the gentry pact discussed below. According to Sedláček, Hrady, 15:249, it is Hrádek Kozí Hřbet, and Břekovec's sons were Taborites in 1430. Cf. Archiv Český, 3 (1843): 502. See $L C, 7: 222$, for Aleš of Dubá's patronage of John.

46. $L C, 7: 224-25$; Sedláček, Hrady, 5:11.

47. $L C, 7: 152,235$.

48. Ibid., pp. 102, 260. In 1418 when he went to Dobričany, he was called Bartoš, the priest of Lomnice. In 1414 Bartholemew came to Brodec from Blizkov, and in 1411 when he went to Blizkov he was called Bartholemew of Lomnice (p. 32). 
definitively declared heretical by the Council. In 1420 they offered their castle as a refuge for Catholic families and priests fleeing the wrath of Hussites in Prague.48

Other nobles not party to the September 2 letter but otherwise known to be friends of the Hussite movement also exercised their rights of patronage on its behalf. Prribek of Klenov, who in the 1420s fought for his radical Hussite neighbors from Tábor, expelled his priest, Matthew of Kdynè, from the altar of Saint John the Evangelist in Tynec, where he had presented him in October 1408. Matthew found a new patron in Lord Menhart of Hradec, who presented him to an altar in Velhartice on March 14, $1418 . .^{50}$ So also John Mladenec of Ujezdec, a neighbor of the lords of Rožmberk, most likely in connection with Cenèk's action, expelled the local priest, Peter of Dobřany. Peter had been presented to Ujezdec in 1401 by Mladenec's father and then on October 5, 1417, found a patron in the local squire, Peter of Cičov. ${ }^{51}$

There were actions, parallel to but apparently independent of the one led by Čenèk, which provided Hussite priests with security. Early in February 1417 the squires Prech of Olbramovice, Herman of Cervený Hrádek, and John of Leskovec, all from south central Bohemia, founded a league for the defense of the chalice which had similarities with the baronial pact of 1415 . The members promised their subjects, including their priests, protection from anathemas and ecclesiastical citations but also vowed to prevent their priests as well as other church authorities from administering such censures. Referring to the taking of communion with wine, the first point reads: "Should they (our priests) try to keep us or our subjects from it, we are to move against them and oppose them, as enemies of the Law of God." ${ }_{52}$

Evidently Anthony, the priest in Olbramovice, had tried to implement the archbishop's instructions of January 10 and had prohibited the use of the chalice in communion. Either he or his patrons must have experienced a change of heart since October 3,1415, when he had been provided with that office by Prech and his brothers of Olbramovice. After his Hussite patrons had expelled Anthony on February 12, 1417, he went to the church in Barov (Borá or Lhota) with the consent of the abbot of the Cistercian monastery in Sedlec. ${ }^{53}$

49. Ibid., pp. 179, 273 (Piračov). Medenec's last act as a patron was on February 18, 1417. For the Ričany family in 1420 see Tomek, Dĕjepis, 3:119-20.

50. LC, 6:261, 7:253; cf. Sedláček, Hrady, 9:156.

51. $L C, 6: 47,7: 242$; cf. Sedláček, Hrady, 11:262.

52. The document is published in Bartholemew Paprocki, O stavn rytirském a rozmnožení jeho jak dávno a odkud který rod a erb do tohoto království príš́l, vol. 3 (Prague, 1602), p. 82. It is dated 1417. The expulsion of Anthony suggests that the pact was formed either in January or early February. It is translated in Klassen, "Noble Patronage and Politics," appendix 3.

53. LC, 7:176, 217; Sedláček, Hrady, 15:245. One of the brothers, Kuneš, was in the service of both kings, Wenceslas and Sigismund. 
Herman of Hrádek, one of the other known members of the pact, also ousted a Catholic priest from church office. Herman shared the patronage in the Kosova Hora parish as well as in the chapel of Saint Margaret and was sole patron of another chapel there. ${ }^{54}$ By August 11, 1417, he had expelled Wenceslas of Sedlec, the altarist of Saint Margaret's, whom he had presented there in 1412. On August 11 Wenceslas was confirmed to the church of Bohumilice under the patronage of Conrad of Vimberk, and through the intervention of the archbishop, after the priest there resigned without explanation. Most likely Lord Conrad arranged for his resignation, if indeed the language in the confirmation is not simply a euphemism for expulsion. ${ }^{55}$ Judging from the fact that they were not confirmed to any new office, the other priests to whom Herman had been patron were probably not expelled. Presumably his religious beliefs were not offensive to them, although in the case of the parish, Herman may have had to contend with opposition from the copatrons. The third known member of the pact, John of Leskovec, who was also a party to the September letter, was the patron of two parishes, but it appears that the priests he presented in 1412 and 1413 accepted his religious views. ${ }^{56}$ Neither of them was confirmed into other offices.

The pact of the gentry was formed at a time when there seemed to be a vacuum in the leadership of the Hussite movement. The leading baron, Lord Ceněk, had taken up negotiations with the heir apparent to the throne, King Sigismund, an avowed enemy of the movement, while at the same time he was urging the university masters to suppress the more radical popular expressions of religious renewal. Ceněk had not yet begun to supply the radical priests with parishes. Simultaneously the movement was coming under attack from the archbishop. Thus, independent of the barons these squires sought to provide some leadership and at least defend their own domains from the reactionary swing which they felt was developing. Manifestations such as theirs perhaps induced Ceněk to temper his hostility toward the radicals and to embark on the course which sought to bring them into the Hussite church established along moderate lines under the leadership of the university. They may also have had some influence on the university's decision of March 10 to declare itself officially in agreement with the use of wine for lay people in communion. ${ }^{57}$

54. $L C, 6: 24,260 ; 7: 21,56$.

55. Wenceslas, "ad presentationem famosi viri Conradi clientis de Wintemberg," went "ad ecclesiam parrochialem in B. ac ex provisione d. Conradi, Archiepiscopi Pragensis per liberam resignacionem Nicolai clerici ultimi rectoris vacantem in manibus nostris factam" (ibid., 7:56, 236).

56. Ibid., pp. 43 (Zářec) and 79 (Zvonějov).

57. For the university's action see Jiří Kejř, "Deklarace pražské university z 10. března 1417 o prijímání pod oboji a její historické pozadí," Sborník historický, 8 (1961): 133-54. Cf. Kaminsky, $H H R$, p. 239 and passim. 
Other references in the literature of the period, combined with the data from the Libri Confirmationum, show that the nobility's action to defend Hussite priests extended beyond the known members of the leagues and included one noblewoman. In 1417 an anonymous writer wrote a series of verses, Sermones ad Bohemos, in which he praised those who defended orthodox Catholicism and damned those who fostered the Hussites. In the latter category he placed Lady Anna of Mochov, the widow of John Kamenice of Ustí. Alluding to Biblical and classical figures, he addressed her as "you most fierce Jezebel, you persecute a priest, a man as just as Abel, who in Ústí suffered abuses from you. Just as Helias, so you shall writhe in Hell. . ." "58 The incident to which he referred was Anna's removal of Benedict, from a chapel near Hradišstè, the site of an old castle a little over a mile from Ústí, where Tábor, one center of radical Hussitism, was later built. She, with her sons John and Procop, had presented Benedict there in October 1414. Benedict, in defiance of his patrons, remained true to the Roman faith and lost his position to an utraquist. However, he found a church in Pravonin under the patronage of the monastery in Lounovice and was confirmed on February 18, 1417.59 Since the author of Sermones singled out Lady Anna for vilification, and since her sons later that year presented an orthodox priest, she was most likely the moving force behind Benedict's ejection.

Far from all of the over two hundred churches to which Hussite nobles owned patronage experienced a change of priest during the religious upheavals which followed Hus's death. To some churches Hussite patrons had earlier appointed men who shared their sympathies for reform. Other priests, sensing the direction in which their lords were moving, adapted their own religious views accordingly in order to keep their jobs and incomes. ${ }^{60}$ Furthermore, not all expelled Catholics necessarily found a patron and thus do not appear in the Libri Confirmationum. But it is clear that Hussite nobles made use of their rights of patronage on behalf of their own religious goals to the advantage of the movement in general.

58. Palacký, Documenta, p. 697. The work is undated, but Kaminsky, $H H R$, p. 247, n. 78, places it in the second half of 1417. The author evidently did not know of Procop and John of Usti's (Anna's sons) presentation of a Romanist priest who was confirmed on November 19. (The date is October 19, but since the confirmation falls in the November progression of dates, it must be a mistake.) This was done in cooperation with the archbishop who had deprived the previous rector of his office for heresy. The author pointedly excluded only Ulrich of the Ustí clan from damnation. He noticed the confirmation of the orthodox priest of the lords of Borotin on October 23. The Borotins had also supported Hus earlier, but were praised in the Sermones for their change of heart. Since presentation was a publicly announced event, preceding confirmation by several weeks, the Sermones must have been written in October.

59. $L C, 7: 131,218$. In 1417 Benedict was called "Benessio, olim capellano in Hradisst."

60. For references to priests who regretted their abdication from the Catholic faith see Joseph Schlenz, Das Kirchenpatronat in Böhnen (Prague, 1928), p. 131. 
The information derived from the episcopal confirmation records, showing the activity of Hussite patrons, puts into more accurate perspective the aristocratic contribution to the Hussite revolution. Historians have mostly emphasized those forces of the revolution emanating from Prague and the rural non-noble communities. Bartoš, although he discusses Lord Cenĕk's leadership, interprets the defection in 1417 and 1418 of several nobles to King Sigismund's party as the end of effective noble support. Henceforth, he stresses, leadership for the movement came from Prague priests such as Jakoubek of Stríbro and John Želivský and similar men from the country. ${ }^{61}$ Josef Macek, discounting the nobles' efforts entirely, mentions only the September 2 protest letter, for which he gives the gentry most of the credit. ${ }^{62}$ Ferdinand Seibt grants that the policy of the Czech nobility was no less dynamic than that of the "masters, nationalists, republicans and brotherhoods [such as the Taborites]." ${ }^{\prime 3}$ But he leaves unanalyzed the nobles' policy and contribution to the movement. Kaminsky restricts himself to the activities of Cenèk of Vartemberk. $^{64}$

The success of the Hussite revolution, albeit of short duration, both in Prague and the country, owed more to the nobility than has generally been recognized. The assistance from the aristocracy, acting as church patrons, made possible the later achievements of Hussitism in both its Prague and its rural plebeian settings. Hussite nobles protected their priests on domains in eastern Bohemia, starting from the north around Železný Brod past Jičín, Podébrady, Hradec Králové, Litomyšl, Chrudim, Cáslav, Lipnice and to the Rožmberk domains just south of Tábor. This was exactly the region where Hussitism enjoyed its greatest strength in the years following. It is no coincidence that in this region were the two main centers of popular and radical Hussitism, Hradec Králové and Tábor, to which flocked the masses in the hope of finding a new world. It was the priests to whom the Hussite nobles had given shelter on their domains and in their parishes who had awakened these ideas in them. Although Prague did not always find itself in agreement with its rural brothers and sisters, they were the ones who defended the city, besieged by Sigismund's armies in 1420 and after, and saved the revolution. The nobles, too, disapproved of the revolutionary developments which dominated the country after 1419. Nevertheless, it was through their help that the radicals had been given a breathing spell in 1417 and 1418, in which they gathered strength for the struggles ahead.

61. Bartoš, Husitská revoluce, 1:56-59. $1: 178$.

62. Josef Macek, Tábor v husitském revolučnim hnutí, 2 vols. (Prague, 1952-55),

63. Ferdinand Seibt, Hussitica: Zur Struktur einer Revolution (Cologne, 1965), pp. $186-87$.

64. Kaminsky, $H H R$, pp. $240-53$. 